\title{
Mechanism of hydrogen on cervical cancer suppression revealed by high-throughput RNA sequencing
}

\author{
JING CHU*, JINGHAI GAO*, JING WANG, LINGLING LI, GUOQIANG CHEN, \\ JIANHONG DANG, ZHIFENG WANG, ZHIJUN JIN and XIAOJUN LIU
}

\begin{abstract}
Department of Obstetrics and Gynaecology, Changzheng Hospital, Naval Medical University, Shanghai 200003, P.R. China
\end{abstract}
Received December 10, 2020; Accepted April 14, 2021

DOI: $10.3892 /$ or.2021.8092

\begin{abstract}
Cervical cancer is considered one of the diseases with the highest mortality among women and with limited treatment options. Hydrogen $\left(\mathrm{H}_{2}\right)$ inhalation has been reported to have a variety of tumor-suppressive effects, but the exact mechanism remains unclear. In the present study, HeLa cervical cancer cells and HaCaT keratinocytes treated with $\mathrm{H}_{2}$, and a HeLa xenograft mouse model subjected to $\mathrm{H}_{2}$ inhalation were established. TUNEL, Cell Counting Kit-8 and Ki67 staining assays were used to detect cell apoptosis and proliferation. Oxidative stress was determined according to the levels of reactive oxygen species, malondialdehyde and superoxide dismutase. Tumor growth was recorded every 3 days, and the excised tumors were stained with hematoxylin and eosin. High-throughput RNA sequencing and subsequent Gene Ontology (GO) enrichment analysis were performed in HeLa-treated and un-treated HeLa cells. The expression of hypoxia-inducible factor (HIF)- $1 \alpha$ and NF- $\kappa$ B p65 was verified by western blotting, immunohistochemistry and reverse transcription-quantitative PCR. The results revealed an increased apoptosis rate, and reduced cell proliferation and oxidative stress in $\mathrm{H}_{2}$-treated HeLa cells but not in $\mathrm{HaCaT}$ cells. Similarly, decreased tumor growth and cell proliferation, and enhanced cell apoptosis were observed in $\mathrm{H}_{2}$-treated HeLa tumors. RNA sequencing and GO analysis suggest that downregulated HIFIA (HIF-1 $\alpha$ mRNA) and RelA (NF-кB p65) levels, and reduced $N F-\kappa B$ signaling were associated with the antitumor effect of $\mathrm{H}_{2}$. Finally, decreased HIF-1 $\alpha$ and $\mathrm{NF}-\kappa \mathrm{B}$ p65 expression both at the transcriptional and
\end{abstract}

Correspondence to: Professor Zhijun Jin or Professor Xiaojun Liu, Department of Obstetrics and Gynaecology, Changzheng Hospital, Naval Medical University, 415 Fengyang Road, Shanghai 200003, P.R. China

E-mail: j_zj888@163.com

E-mail: liuxiaojun@smmu.edu.cn

\section{*Contributed equally}

Key words: cervical cancer, hydrogen gas, RNA sequencing, hypoxia-inducible factor $1 \alpha$, nuclear factor- $\mathrm{kB}$ p65 translational levels were observed in $\mathrm{H}_{2}$-treated HeLa cells and in HeLa-derived tumors. In conclusion, the present study reveals a novel mechanism of $\mathrm{H}_{2}$ against cervical cancer, which may serve as a potential therapeutic target in clinical practice.

\section{Introduction}

Cervical cancer is the fourth most common type of cancer and the fourth leading cause of cancer-associated mortality among women worldwide (1). In addition, cervical cancer is the second leading cause of cancer-associated mortality in women aged 20-39 years in the USA, and it was estimated that there may be 13,800 new cases and 4,290 mortalities in 2020 (2). Radical hysterectomy with pelvic lymphadenectomy is the standard recommended surgical therapy for patients with early-stage cervical cancer (3). However, this method also increases the number of circulating tumor cells, and promotes cancer progression and metastasis (4). In addition to surgical therapy, molecular-targeted strategies have recently received attention in the field of cancer treatment. However, molecular-targeted strategies have not shown significant benefit in the majority of patients with cervical cancer, as these precision drugs are available for only $3-13 \%$ of patients $(5,6)$. Thus, alternative treatments for patients with cervical cancer are needed.

Molecular hydrogen $\left(\mathrm{H}_{2}\right)$ biology and $\mathrm{H}_{2}$ therapy are novel and rapidly developing areas of research (7-9). $\mathrm{H}_{2}$ has been shown to exert antioxidant and anti-inflammatory effects (10), and to protect neurons from oxidative stress injury during cerebral ischemia-reperfusion (11). Importantly, since the tumorigenesis and progression of cancer are closely associated with the levels of peroxidation and inflammation, $\mathrm{H}_{2}$ may play a role in tumor regulation in endometrial (12), lung (13) and breast cancer (14). A prospective follow-up study of 82 patients with stage III and IV cancer, including lung, pancreatic and gynecological cancer (including cervical cancer), revealed significant improvements in fatigue, insomnia, anorexia, pain and physical status after 4 weeks of $\mathrm{H}_{2}$ inhalation (15). However, the potential antitumor mechanism of $\mathrm{H}_{2}$ intervention in cervical cancer is currently unknown.

High-throughput RNA sequencing is a powerful method for revealing transcriptional and non-transcriptional signatures in cells and animals (16). It maximizes the identification of the regulatory effects of different treatments at the genetic level. The human cervical adenocarcinoma HeLa cell line expresses 
over 10,000 proteins and is considered the most commonly analyzed cells in cervical cancer research $(17,18)$. Previous studies reported that HeLa cells can be used in vitro (19) and in in vivo xenotransplant models (20) to simulate the process of cervical cancer. In addition, HeLa cells have been used to investigate the regulatory role of $\mathrm{H}_{2}$ in Wnt/ $\beta$-catenin signaling (21). But the tumor inhibitory effect of $\mathrm{H}_{2}$ and its related mechanism in HeLa cells remain unknown. Thus, RNA sequencing of control and $\mathrm{H}_{2}$-treated HeLa cells may be helpful for identifying the potential antitumor mechanism of $\mathrm{H}_{2}$ in cervical cancer.

The present study demonstrated that treatment with $66.7 \%$ $\mathrm{H}_{2}$ significantly elevated the apoptosis rate, and reduced the cell proliferation and oxidative stress of HeLa cells in vitro. Furthermore, tumor growth and cell death were also observed in $\mathrm{H}_{2}$-treated HeLa tumors. Decreased hypoxia inducible factor $(H I F) 1 A$ and RELA proto-oncogene, $\mathrm{NF}-\kappa \mathrm{B}$ subunit (RelA) expression levels were detected in the $\mathrm{H}_{2}$ group through RNA sequencing. The expression of HIFlA and RelA and their encoded protein expression were further confirmed by reverse transcription-quantitative PCR (RT-qPCR), western blotting, and immunohistochemistry (IHC).

\section{Materials and methods}

Cell line and cell experiments. The human cervical cancer HeLa cell line and nontumor HaCaT keratinocytes were purchased from the American Type Culture Collection. Cells were cultured in DMEM (Gibco; Thermo Fisher Scientific, Inc.) supplemented with $10 \%$ filtered FBS (Gibco; Thermo Fisher Scientific, Inc.) at $37^{\circ} \mathrm{C}$ in a humidified $5 \% \mathrm{CO}_{2} / 95 \%$ air environment. For $\mathrm{H}_{2}$ intervention, $\mathrm{H}_{2}$ gas was produced by a $\mathrm{H}_{2}-\mathrm{O}_{2}$ nebulizer (AMS-H-01; Asclepius), and $\mathrm{HeLa}$ and $\mathrm{HaCaT}$ cells were incubated at $37^{\circ} \mathrm{C}$ in a mixture of $33.3 \% \mathrm{H}_{2} / 33.3 \% \mathrm{~N}_{2} / 33.4 \% \mathrm{O}_{2}$ or $66.7 \% \mathrm{H}_{2} / 33.3 \% \mathrm{O}_{2}$ environment for $1 \mathrm{~h}$ every $12 \mathrm{~h}$. Cisplatin was obtained from APeXBIO Technology LLC (cat. no. A8321). Our preliminary results suggested that the $\mathrm{IC}_{50}$ of cisplatin treatment of $\mathrm{HeLa}$ cells for $24 \mathrm{~h}$ is $12 \mu \mathrm{g} / \mathrm{ml}$, which is consistent with previously reported results (22). Cisplatin was used in the present study at a concentration of $5 \mu \mathrm{g} / \mathrm{ml}$. After 7 days of $\mathrm{H}_{2}$ treatment, cells were evaluated for their viability, apoptosis, reactive oxygen species (ROS), malondialdehyde (MDA) and superoxide dismutase (SOD) levels. In addition, RNA was isolated for RNA sequencing. Cells cultured under a normal environment were used as control.

Animal experiments. A total of 22 female athymic BALB/c nude mice (age, 5-6 weeks old; weight, 20-25 g) were obtained from Jackson Laboratory and housed in a pathogen-free facility with temperature of $18-29^{\circ} \mathrm{C}$, relative humidity of $40-70 \%$, 12-h light/dark cycle, and free access to food and water. HeLa cells ( $1 \times 10^{7}$ cells in $\left.200 \mu \mathrm{l} \mathrm{PBS}\right)$ were subcutaneously injected into the left armpit of nude mice. Tumor-bearing mice were monitored by body condition scoring index and clinical evaluations every day, and were euthanized by administration of an overdose of pentobarbital sodium $(100 \mathrm{mg} / \mathrm{kg})$ if they exhibited either a $>10 \%$ decrease in body weight compared with pre-injection body weight or if their activity level declined due to tumor burden. In total, 4 tumor-bearing mice were euthanized who reached the aforementioned humane endpoints. At 7 days post-injection, the remaining tumor-bearing mice were randomly divided into two groups: The group housed under normal conditions (control group, $\mathrm{n}=9$ ) and the $\mathrm{H}_{2}$ intervention group $\left(\mathrm{H}_{2}\right.$ group, $\left.\mathrm{n}=9\right)$. To establish a $\mathrm{H}_{2}$ intervention model, mice were kept in a mixture of $66.7 \% \mathrm{H}_{2} / 33.3 \% \mathrm{O}_{2}$ environment for $30 \mathrm{~min}$ per day (11), and after 27 days, the mice were sacrificed with $100 \mathrm{mg} / \mathrm{kg}$ pentobarbital sodium as evidenced by the disappearance of breathing and heartbeat to collect the tumors. Tumor volumes were estimated as the length $\mathrm{x}$ width ${ }^{2} \mathrm{x} 0.5$ every 3 days starting from 7 days after cell injection. The maximum tumor volume observed in the present study was $1,582 \mathrm{~mm}^{3}$. All animal experiments were performed in accordance with the National Institutes of Health (NIH) Guide for the Care and Use of Laboratory Animals, and were approved by the Ethics Committee for Animal Studies of Naval Medical University (approval no. 202027).

Cellular apoptosis and proliferation assay. TUNEL assay by immunofluorescence staining was performed to determine the cellular apoptosis rate. Briefly, $2 \times 10^{4} \mathrm{HeLa}$ or HaCaT cells were seeded into 48-well plates and, after $\mathrm{H}_{2}$ intervention, the cells were fixed with $4 \%$ paraformaldehyde for $10 \mathrm{~min}$ at room temperature. After permeabilization with $0.1 \%$ Triton X-100 (Sigma-Aldrich; Merck KGaA) for $10 \mathrm{~min}$ at room temperature, the cells were blocked with 5\% BSA (Sigma-Aldrich; Merck $\mathrm{KGaA}$ ) for $10 \mathrm{~min}$ at room temperature. Furthermore, the In situ Cell Death Detection kit (cat. no. 11684809910; Roche Diagnostics) was used according to the manufacturer's protocol, and cells were then counterstained with DAPI (Sigma-Aldrich; Merck KGaA) for nuclear staining and observed through a fluorescence microscope (Olympus Corporation). The percentage of TUNEL-positive cells was calculated as the ratio of the number of TUNEL-positive nuclei/total number of nuclei, which were counted in three different random fields of view.Cell proliferation was evaluated using a Cell Counting Kit (CCK)-8 assay (cat. no. C0037; Beyotime Institute of Biotechnology) following the manufacturer's instructions. The absorbance at $450 \mathrm{~nm}$ was detected using a microplate reader (BioTek Instruments, Inc.).

Cellular oxidative stress detection. The level of ROS was determined using the Cellular ROS Assay kit (cat. no. ab113851; Abcam) according to the manufacturer's instructions. The ROS level was calculated as ROS positive area/total area $\mathrm{x} 100 \%$. In addition, MDA and SOD levels were detected using the commercially available test kits Lipid Peroxidation (MDA) Assay kit (cat. no. ab118970; Abcam) and SOD Colorimetric Activity kit (cat. no. EIASODC; Invitrogen; Thermo Fisher Scientific, Inc.) according to the manufacturer's protocol.

Hematoxylin and eosin (H\&E) staining and immunohistochemistry (IHC). HeLa tumors fixed in $4 \%$ paraformaldehyde were dehydrated and then embedded in paraffin. Next, samples were sectioned at $5-\mu \mathrm{m}$ thickness and stained with hematoxylin and eosin (H\&E). Tumor histopathological changes were captured with an optical microscope (Olympus Corporation).

For IHC, the sections were deparaffinized, hydrated at $70^{\circ} \mathrm{C}$ in xylene and microwaved at full power for $20 \mathrm{~min}$ for 
antigen retrieval using sodium citrate ( $\mathrm{pH}$ 6.0). In addition, $5 \%$ BSA was used as the blocking reagent overnight at $4^{\circ} \mathrm{C}$. Next, the slides were incubated with anti-HIF-1 $\alpha$ primary antibody (1:100; cat. no. ab51608; Abcam), anti-NF-кB p65 primary antibody (1:200; cat. no. ab16502; Abcam) or anti-Ki67 primary antibody (1:200; cat. no. ab15580; Abcam) overnight at $4^{\circ} \mathrm{C}$. The next day, the slides were washed three times with PBS and incubated with a goat anti-rabbit polyclonal HRP-conjugated secondary antibody (1:50; cat. no. 32260; Thermo Fisher Scientific, Inc.) for $2 \mathrm{~h}$ at room temperature. After diaminobenzidine staining (Invitrogen; Thermo Fisher Scientific, Inc.), images were captured with an optical microscope and analyzed using ImageJ 1.53 software (NIH). TUNEL assay by IHC was performed with DeadEnd ${ }^{\mathrm{TM}}$ Colorimetric TUNEL system (cat. no. G7360; Promega Corporation) according to the manufacturer's instructions.

RNA sequencing. cDNA libraries were constructed in a strand-specific manner from $4 \mu \mathrm{g}$ DNase-treated RNA using TruSeq Stranded Total RNA Library Prep kit (cat. no. 20020597; Illumina, Inc.). Total RNA, including mRNA and small RNA (circRNA, IncRNA, and miRNA) was then fragmented, subjected to two rounds of cDNA synthesis, and adapters were then ligated to double-strand cDNA. All libraries were sequenced on Illumina NovaSeq 6000 and HiSeq X Ten platforms (Illumina, Inc.), generating 100-bp paired-end reads. High-quality reads were obtained by trimming adapter sequences, invalid and low-quality reads from the raw reads (quality control). The clean reads were then mapped to the human genome by HISAT2 software (v 2.1.0) using default parameters. Next, transcript assemblies were constructed using StringTie software (v 1.3.6; The Center for Computational Biology at Johns Hopkins University) to merge transcripts, and DESeq2 software (v 2.11.40.2; Bioconductor, Inc.) was used to compute differential expression.

Bioinformatic analyses. Multivariate analysis and principal component analysis were performed by ClustVis online tool (https://github.com/fw1121/ClustVis) (23). Gene Ontology (GO) enrichment analysis was carried out using DAVID bioinformatics tool (https://david.ncifcrf.gov/tools.jsp) (24). A hypergeometric test (Fisher's exact test) was used to calculate the statistical significance of gene overrepresentation, followed by a Bonferroni correction for multiple comparisons to estimate the proportion of enriched genes that may occur by chance for the given set of genes. Heatmaps and volcano plots were generated using TBtools ( $\mathrm{v}$ 1.055; programmed by C.J. Chen). Fold-change (FC) was calculated as the mean value of RNA reads in $\mathrm{H}_{2}$ groups/mean value in controls.

Western blotting. Protein samples from HeLa cells in the control and $\mathrm{H}_{2}$ treatment groups were lysed with Tissue or Cell Total Protein Extraction kit (cat. no. C510003; Sangon Biotech Co., Ltd.) following the manufacturer's protocol. Protein concentration was determined using a BCA Protein Assay kit (cat. no. P0010; Beyotime Institute of Biotechnology). Equal quantities of protein ( $20 \mu \mathrm{g}$ per lane) from the lysate of control or $\mathrm{H}_{2}$ treatment groups were subjected to SDS-PAGE. After transferring to a PVDF membrane and blocking with 5\% skimmed milk for $2 \mathrm{~h}$ at room temperature, the membrane was incubated overnight at $4^{\circ} \mathrm{C}$ with specific primary antibodies against HIF-1 $\alpha$ (cat. no. ab51608), GAPDH (cat. no. ab8245), $\mathrm{NF}-\kappa \mathrm{B}$ (cat. no. ab16502) or lamin B1 (cat. no. ab16048) (all from Abcam) at a 1:1,000 dilution. After washing three times, the membrane was incubated with HRP-labeled goat anti-rabbit $\operatorname{IgG}(\mathrm{H}+\mathrm{L})$ or HRP-labeled goat anti-nouse $\mathrm{IgG}$ $(\mathrm{H}+\mathrm{L})$ secondary antibody $(1: 2,000$ both; cat. nos. A0208 and A0216, respectively; both from Beyotime Institute of Biotechnology) for $2 \mathrm{~h}$ at room temperature, and then developed with an ECL solution (cat. no. P0018; Beyotime Institute of Biotechnology). For semi-quantitative analysis, the bands were semi-quantified using ImageJ software (v 1.53; National Institutes of Health, USA), and the data were normalized relative to the cytoplasmic control GAPDH or the nuclear control lamin B1 as the integral optical density ratio.

Reverse transcription-quantitative PCR (RT-qPCR). Total RNA was extracted from tumors or cultured HeLa cells with TRIzol $^{\circledR}$ (Invitrogen; Thermo Fisher Scientific, Inc.), and its quality and quantity were assessed using NanoDrop2000c (NanoDrop Technologies; Thermo Fisher Scientific, Inc.). RNA was then reverse transcribed with random hexamers (cat. no. N8080127; Invitrogen; Thermo Fisher Scientific, Inc.) and SuperScript II kit (cat. no. 18064014; Invitrogen; Thermo Fisher Scientific, Inc.). qPCR was performed with specific primers and SYBR-Green PCR Master Mix kit (cat. no. 4368702; Applied Biosystems; Thermo Fisher Scientific, Inc.) according to the manufacturer's protocol. An 8- $\mu$ l (final volume) reaction system was established, which contained $300 \mathrm{nM}$ primers. The thermocycling conditions were as follows: Initial denaturation start cycle at $95^{\circ} \mathrm{C}$ for $3 \mathrm{~min}$, followed by 32 cycles at $95^{\circ} \mathrm{C}$ for $10 \mathrm{sec}$ and then $59^{\circ} \mathrm{C}$ for $30 \mathrm{sec}$. The expression levels of HIFIA and RelA were calculated by the $2^{-\Delta \Delta \mathrm{Cq}}$ method (25), normalized to that of GAPDH and converted to FC values. The following pairs of primers were used: HIFlA forward, 5'-GCACAGTTTGAC TTGACTGGAC-3' and reverse, 5'-TTCTTGGAGCCTGTT CTGTGG-3'; RelA forward, 5'-ACGAGCAGATGGTCAAGG AG-3' and reverse, 5'-CTTCCATGGTCAGTGCCTTT-3'; and GAPDH forward, 5'-GGAGCGAGATCCCTCCAAAAT-3' and reverse, 5'-GGCTGTTGTCATACTTCTCATGG-3'.

Statistical analysis. Data are expressed as the mean \pm standard error of mean. Differences between two groups were compared using unpaired Student's t-test, while multiple comparisons were performed with one-way ANOVA followed by Tukey's post hoc test. In addition, multiple comparisons in two independent variables were performed with two-way ANOVA followed by Bonferroni's post hoc test. Statistical analysis was performed using SPSS v 23.0 (IBM Corp.). $\mathrm{P}<0.05$ was considered to indicate a statistically significant difference.

\section{Results}

$\mathrm{H}_{2}$ intervention reduces HeLa cell proliferation, and promotes cellular apoptosis and oxidative stress in a selective and dose-dependent manner. Firstly, the effects of $\mathrm{H}_{2}$ treatment in HeLa cells were explored in vitro. As shown in Fig. 1A and $\mathrm{B}$, the ratio of TUNEL-positive cells among all $\mathrm{H}_{2}$-treated Hela cells was significantly increased compared with that 
A
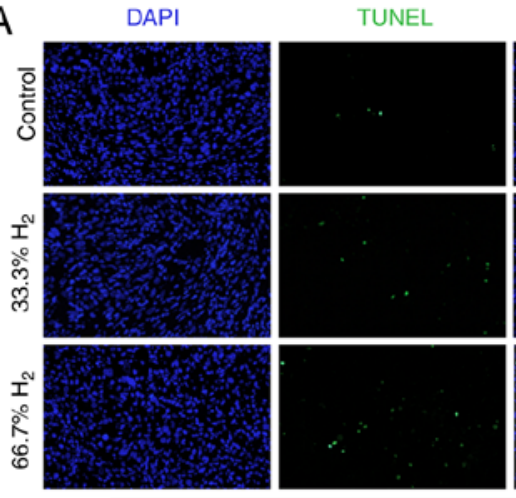

HeLa

TUNEL
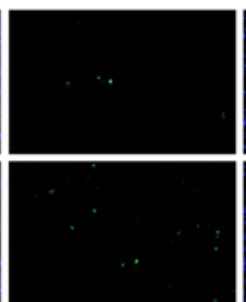

Merged
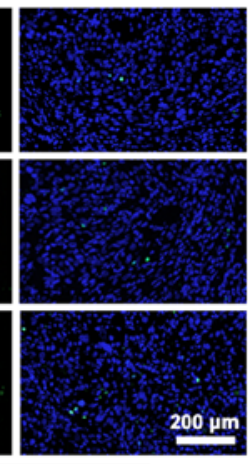

$200 \mathrm{\mu m}$
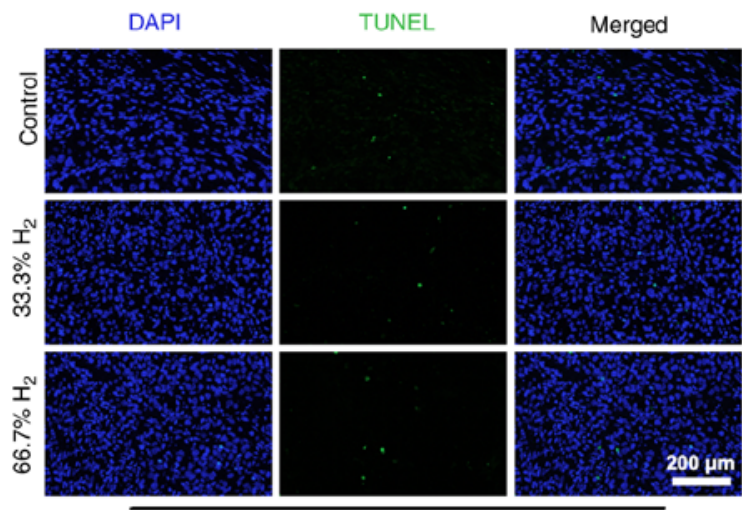

HaCaT
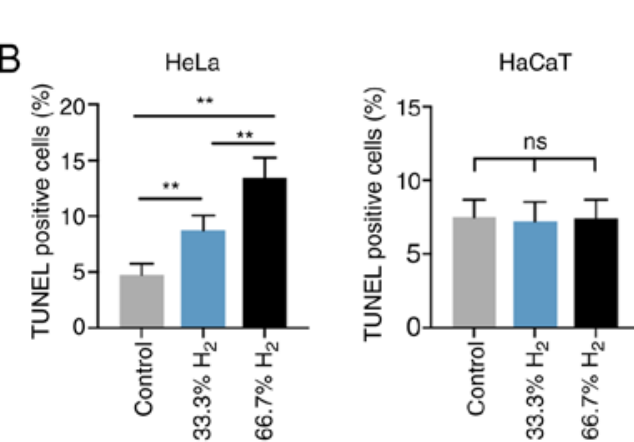

C

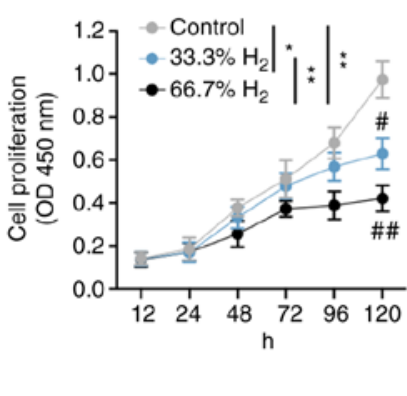

$\mathrm{HaCaT}$

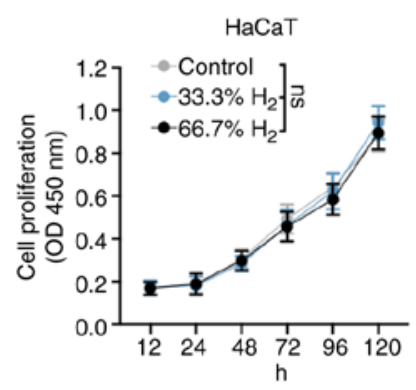

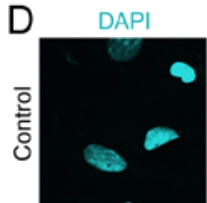

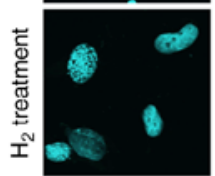

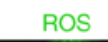

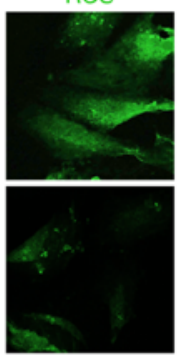

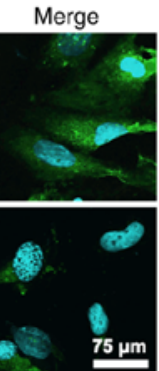
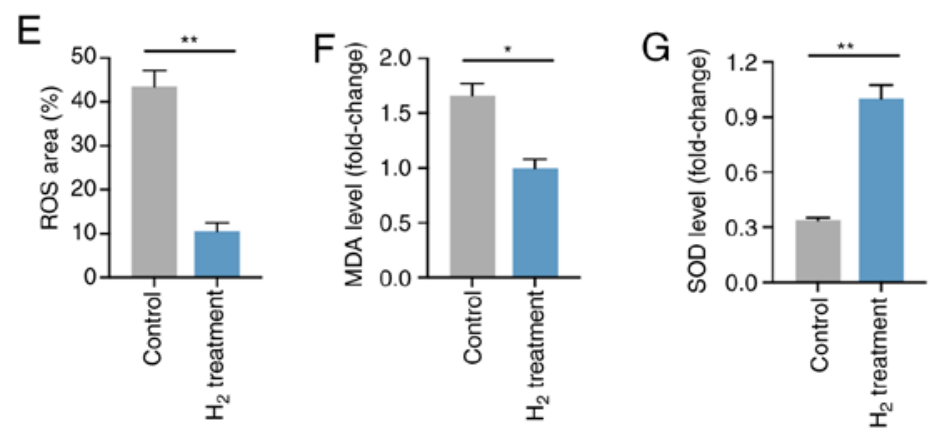

Figure 1. Decreased cell proliferation, and increased cell death and oxidative stress level in $\mathrm{H}_{2}$-treated HeLa cervical cancer cells. (A) TUNEL staining of $\mathrm{HeLa}$ and $\mathrm{HaCaT}$ cells in the control, $33 \% \mathrm{H}_{2}$ and $66.7 \% \mathrm{H}_{2}$ groups. Furthermore, $5 \mu \mathrm{g} / \mathrm{ml}$ cisplatin treatment was used as a positive control (scale bar, $200 \mu \mathrm{m}$ ). (B) Statistical results of TUNEL-positive HeLa and $\mathrm{HaCaT}$ cells in the control, $33 \% \mathrm{H}_{2}$ and $66.7 \% \mathrm{H}_{2}$ groups ( $\mathrm{n}=4$ per group). ${ }^{* *} \mathrm{P}<0.01$, ns indicates no significant difference. (C) Cell proliferation curves of the control, $33 \% \mathrm{H}_{2}$ and $66.7 \% \mathrm{H}_{2}$ groups in HeLa and HaCaT cells during different time periods ( $\mathrm{n}=3$ per group). ${ }^{*} \mathrm{P}<0.05,{ }^{* *} \mathrm{P}<0.01$ vs. indicated group, and ${ }^{\#} \mathrm{P}<0.05,{ }^{\# \#} \mathrm{P}<0.01$ vs. control group at day 5 , ns indicates no significant difference. (D) Fluorescent staining of ROS in control and $66.7 \% \mathrm{H}_{2}$-treated HeLa cells (scale bar, $75 \mu \mathrm{m}$ ). (E) Statistical results of ROS area (\%) in the control and $66.7 \% \mathrm{H}_{2}$ groups $(\mathrm{n}=4$ per group). ${ }^{* *} \mathrm{P}<0.01$. Statistical results of $(\mathrm{F})$ malondialdehyde (MDA) and (G) superoxide dismutase (SOD) levels in the control and $66.7 \% \mathrm{H}_{2}$ treatment groups (n=5 per group). ${ }^{.} \mathrm{P}<0.05,{ }^{* *} \mathrm{P}<0.01 . \mathrm{H}_{2}$, hydrogen; ROS, reactive oxygen species.

of the controls $(\mathrm{P}<0.01)$. Treatment with $66.7 \% \mathrm{H}_{2}$ markedly increased the apoptosis rate. Importantly, the increase in HeLa cell apoptotic rate induced by $5 \mu \mathrm{g} / \mathrm{ml}$ cisplatin treatment $\left(\mathrm{IC}_{50}=12 \mu \mathrm{g} / \mathrm{ml}\right)$ was consistent with the effect of $66.7 \%$ $\mathrm{H}_{2}$ treatment. Notably, no significant differences in apoptosis rate were observed in $\mathrm{HaCaT}$ cells treated with or without $\mathrm{H}_{2}$ gas. The CCK-8 assay revealed that cell proliferation was reduced after $33.3 \% \mathrm{H}_{2}$ treatment progressively, and $66.7 \%$ $\mathrm{H}_{2}$ further decreased the proliferation of HeLa cells over time but not of HaCaT cells (Fig. 1C). In addition, the effect of time was significant associated with the cell proliferation in both Hela cells and HaCaT cells. These results suggest that $\mathrm{H}_{2}$ has a specific concentration-dependent inhibitory effect on HeLa cells rather than on non-tumor HaCaT cells. Thus,
$\mathrm{H}_{2}$ at a concentration of $66.7 \%$ was then used for the further experiments.

ROS are generated by ageing mitochondria due to overproduction of free radicals and reduced antioxidant defenses $(26,27)$. The present study demonstrated that the ROS level in the $\mathrm{H}_{2}$-treated HeLa cells was markedly reduced compared with that of the control group $(\mathrm{P}<0.01$; Fig. 1D and E), which is consistent with the previously reported anti-oxidative stress activity of $\mathrm{H}_{2}$ gas (10). In addition, the level of MDA, an indicator of lipid peroxidation, was also decreased in HeLa cells treated with $\mathrm{H}_{2}$ (Fig. 1F), whereas an increased level in SOD, an important representative of antioxidant enzymes, was observed in the $\mathrm{H}_{2}$ group compared with that of the controls $(\mathrm{P}<0.01$; Fig. $1 \mathrm{G})$. These results suggested 


\section{A}

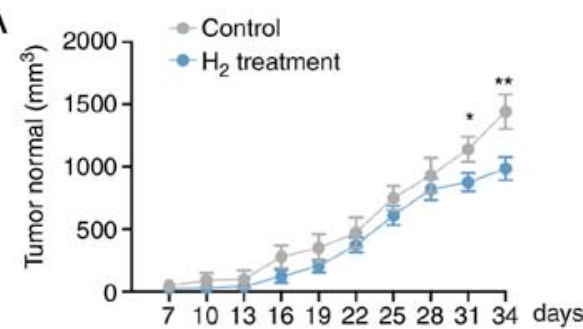

D

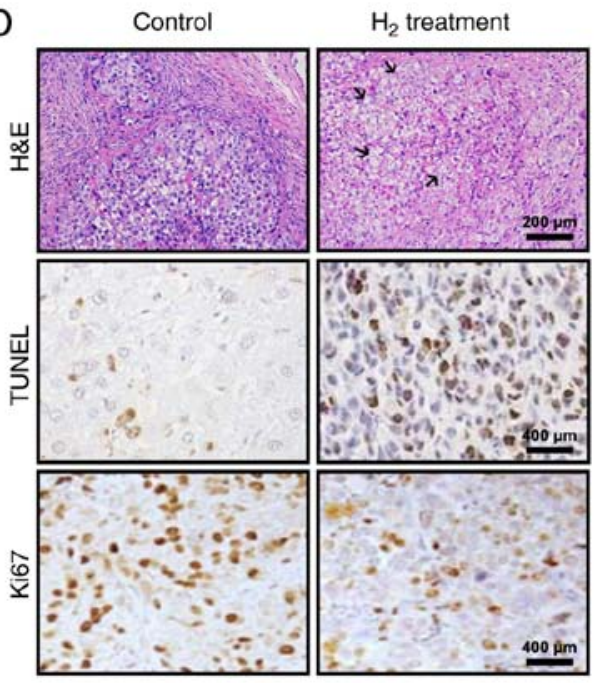

B

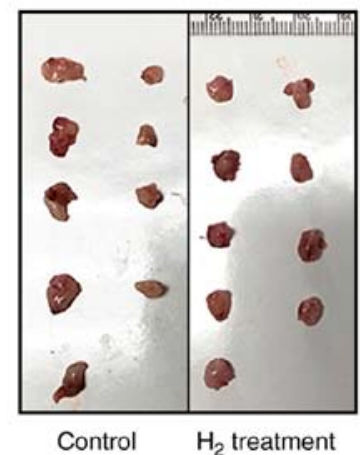

E

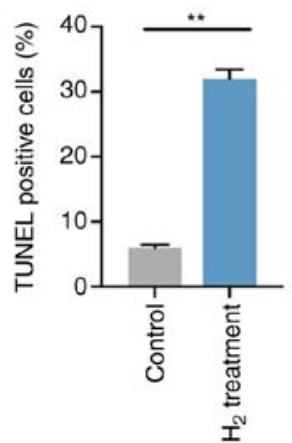

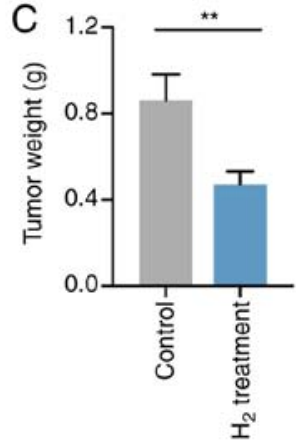

$\mathrm{F}$

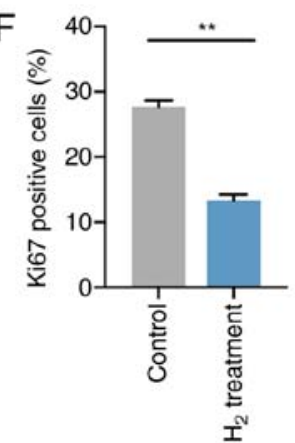

Figure 2. $\mathrm{H}_{2}$ intervention reduces tumor growth in tumor-bearing mice. (A) Tumor volume curves from 7 to 34 days after cell injection in the control and $\mathrm{H}_{2}$ treatment tumor-bearing groups ( $\mathrm{n}=9$ per group). ${ }^{*} \mathrm{P}<0.05,{ }^{* *} \mathrm{P}<0.01$. (B) Images of the excised tumors in control and $\mathrm{H}_{2}$ tumor-bearing mice. $(\mathrm{C}) \mathrm{Statistical}$ results of tumor weight (units, g) in the control and $\mathrm{H}_{2}$ groups ( $\mathrm{n}=9$ per group). ${ }^{* *} \mathrm{P}<0.01$. (D) Hematoxylin and eosin staining (H\&E) and immunohistochemistry for TUNEL and Ki67 staining in control tumor sections or sections after treatment with $\mathrm{H}_{2}$ (scale bar, 200 or $400 \mu \mathrm{m}$ ). Black arrows indicate nucleus fragmentation. Percentage of (E) TUNEL-positive cells or (F) Ki67-positive cells in control and $\mathrm{H}_{2}$-treated tumors ( $\mathrm{n}=5$ per group). ${ }^{* *} \mathrm{P}<0.01$. $\mathrm{H}_{2}$, hydrogen.

that $\mathrm{H}_{2}$ intervention induced HeLa cell apoptosis, inhibited cell proliferation and reduced the oxidative stress level.

Reduced tumor growth is observed in a $\mathrm{H}_{2}$-induced xenograft in vivo model. A total of $1 \times 10^{7} \mathrm{HeLa}$ cells were subcutaneously injected into the left armpit of nude mice, and the tumor volume was recorded every 3 days starting 7 days post-injection (Fig. 2A). At days 31 and 34, the tumor volume in mice under high $\mathrm{H}_{2}$ environment was significantly smaller than that that in the control group $(\mathrm{P}<0.05$ at day 31 and $\mathrm{P}<0.01$ at day 34), which was consistent with the change in tumor weight on day $34(\mathrm{P}<0.01$; Fig. $2 \mathrm{~B}$ and $\mathrm{C})$.

$\mathrm{H} \& \mathrm{E}$ staining revealed that the tumor cell death rate in the $\mathrm{H}_{2}$ xenograft group was elevated, and was accompanied by cell swelling as well as nuclear fragmentation and disintegration (Fig. 2D; black arrows). In addition, $\mathrm{H}_{2}$ treatment significantly increased the apoptosis rate and reduced the cell proliferation of HeLa cells (Fig. 2E and F). Taken together, these data suggested that a high- $\mathrm{H}_{2}$ environment inhibited tumor growth in tumor-bearing mice.

Bulk RNA sequencing of $\mathrm{H}_{2}$-treated HeLa cells and control cells. To investigate the potential mechanism by which $\mathrm{H}_{2}$ inhibits tumor cell growth, whole-genome sequencing was performed (Fig. 3). As shown in Fig. S1A-C, 11 upregulated and 16 downregulated circular RNAs (circRNAs) were determined in $\mathrm{H}_{2}$-treated HeLa cells through the HiSeq4000 platform. In addition, 2 long non-coding RNAs (lncRNAs) were detected to be upregulated, while 6 lncRNAs were downregulated in $\mathrm{H}_{2}$-treated HeLa cells (Fig. S2A-C). A total of 12 hsa-microRNAs (miRNAs or miRs) were found to be upregulated, and 2 miRNAs to be downregulated, including hsa-miR-431-5p and hsa-miR-762 (Fig. S3A-C). Importantly, mRNA sequencing revealed that $10 \mathrm{mRNAs}$ were upregulated in HeLa cells subjected to $\mathrm{H}_{2}$ treatment, and 4 mRNAs were downregulated, including HIF1A, miR23B, miR4651 and RelA (Fig. 4A-C). $m i R 23 B$ and $m i R 4651$ are non-coding RNAs, whereas HIFlA and RelA are the coding genes for HIF-1 $\alpha$ and NF- $\kappa$ B p65 subunit, respectively. These results suggested that the mRNA levels of HIF-1 $\alpha$ and NF- $\mathrm{B}$ p65 subunit were reduced in $\mathrm{H}_{2}$-treated HeLa cells compared with those of the controls.

GO enrichment analysis for HeLa cells with $\mathrm{H}_{2}$ intervention. To further confirm the aforementioned gene regulation in $\mathrm{H}_{2}$-treated HeLa cells, GO enrichment analysis was performed. As shown in Fig. 5A, the biological process (BP), cellular component $(\mathrm{CC})$ and molecular function $(\mathrm{MF})$ were analyzed. 'Translation' and 'NF- $\kappa \mathrm{B}$ signaling' were the two most dominant processes in BP, and gene regulation mainly occurs in the nucleus and non-membrane-bounded organelles. MF analysis revealed that 'DNA and RNA binding' were dominant. GO 


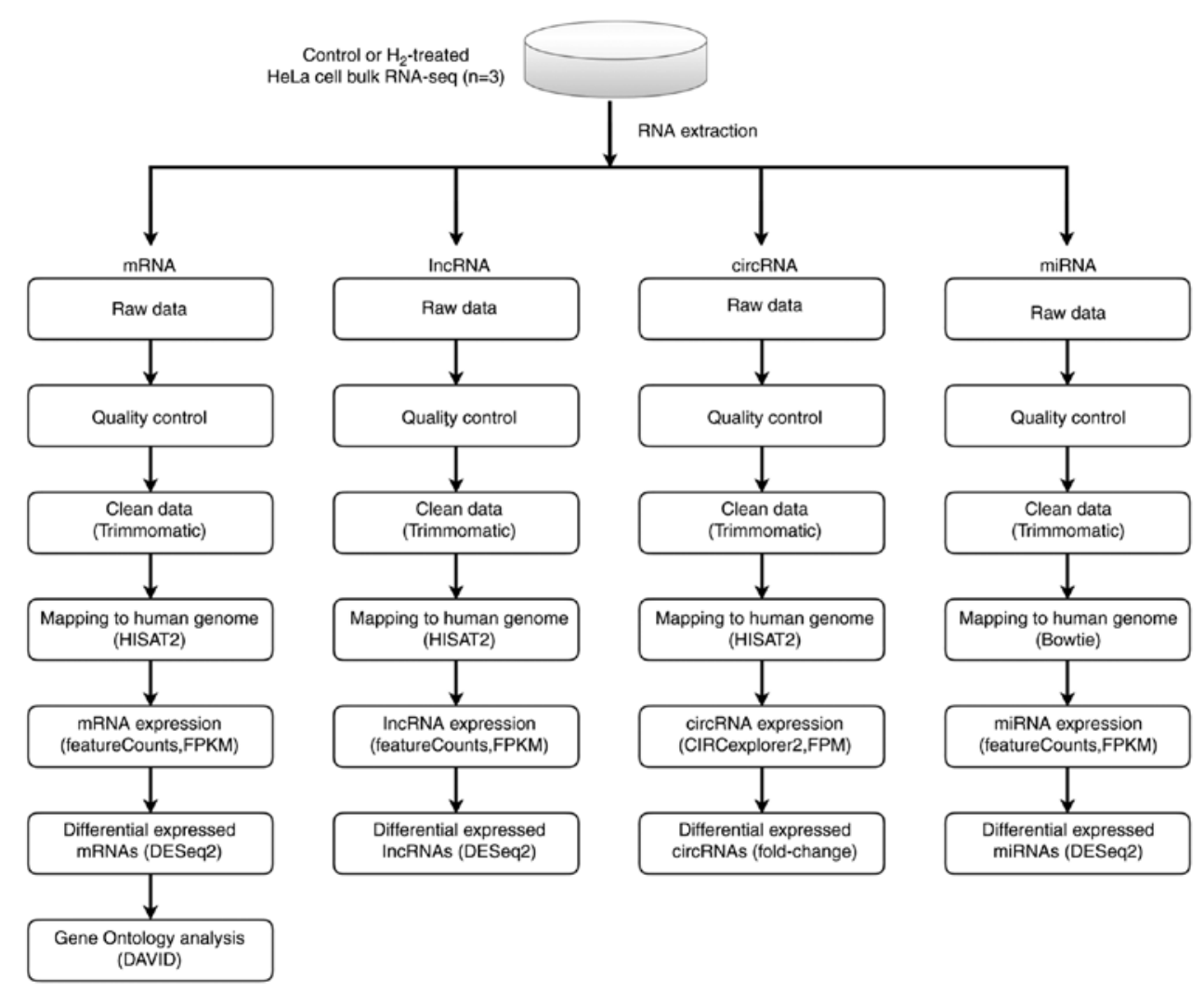

Figure 3. Scheme of whole-genome (RNA) sequencing. RNA sequencing libraries were generated from $4 \mathrm{mg}$ total RNA samples isolated from control or hydrogen-treated HeLa cells using TruSeq Stranded Total RNA Library Prep kit. Sequencing was carried out on Illumina NovaSeq 6000 and HiSeq X Ten platforms. After quality control, the clean reads of circular RNA, long non-coding RNA, microRNA and mRNA were then mapped to the human genome by HISAT2 software, and the analysis was performed using an DESeq2 software. Differential expression analysis was conducted with the DESeq2 platform (n=3 per group). Gene Ontology enrichment analysis of mRNA was performed using DAVID bioinformatics tool.

enrichment scatter plot further indicated that the processes of 'NF- $\mathrm{KB}$ signaling', 'protein transport' and 'multicellular organismal movement' are enriched in $\mathrm{H}_{2}$-treated HeLa cells (Fig. 5B). These results suggested that downregulation of the NF- $\mathrm{KB}$ signaling pathway may be an important target for $\mathrm{H}_{2}$ intervention in HeLa cells.

$H I F-1 \alpha$ and $N F-\kappa B$ p 65 expression levels are downregulated in $\mathrm{H}_{2}$-treated HeLa cells in vivo and in vitro. As the $\mathrm{p} 65$ subunit is a classic active type of the NF- $\kappa B$ family (28), the present study verified the expression levels of NF- $\mathrm{KB}$ p 65 and HIF- $1 \alpha$ in HeLa cells. As expected, western blot analysis demonstrated that the HIF- $1 \alpha$ and NF- $\kappa$ B p 65 protein levels were significantly reduced in $\mathrm{H}_{2}$-treated HeLa cells compared with those in control HeLa cells (Fig. 6A-C). RT-qPCR analysis revealed that the mRNA expression levels of HIF- $1 \alpha$ and NF- $\kappa$ B p65 (HIFlA and RelA) were elevated in HeLa cells (Fig. 6D and E).

The levels of HIF- $1 \alpha$ and NF- $\mathrm{KB}$ p65 were then determined in $\mathrm{HeLa}$ cell-derived tumors. As shown in Fig. 6F-H, IHC demonstrated that the expression of HIF- $1 \alpha$ and NF- $\kappa$ B p 65 in $\mathrm{H}_{2}$-treated HeLa tumors was significantly reduced compared with that of the controls. Furthermore, the mRNA levels in vivo were also investigated, and the results revealed a significant decrease in HIFIA and RelA expression in $\mathrm{H}_{2}$-treated tumors compared with that of control tumors (Fig. 6I and J). These results indicated that the expression levels of HIF-1 $\alpha$ and $\mathrm{NF}-\kappa \mathrm{B}$ p65 were downregulated both in HeLa cells and in HeLa tumors.

\section{Discussion}

Cervical cancer is the fourth most common type of cancer in women worldwide, and $70 \%$ of cervical cancercases are caused by human papilloma virus (HPV)16 and 18 infections (29). HPVs are diverse at the level of genotype and pathogenicity, and can be classified into mucosal or cutaneous according to their epithelial tropism (30). The mucosal high-risk HPV16 and HPV18 are primarily associated with squamous intraepithelial lesions, which may progress to invasive squamous cell carcinoma such as cervical cancer (31). The pathogenic effects of HPV can be avoided by preventive measures, mainly vaccination. Although the currently available immunization methods have been shown to be effective in decreasing cervical cancer, genital warts and anogenital dysplasia, the global vaccination rates remain low, and more effective alternative medical treatments are therefore needed (32).

The present study first determined the pro-apoptotic and anti-proliferative effects of $\mathrm{H}_{2}$ treatment in HeLa cells. A $\mathrm{H}_{2}$ concentration of $33.3 \%$ significantly increased the cell apoptosis and reduced the cell proliferation of HeLa cells but not those of non-tumor HaCaT cells. Furthermore, a high concentration of $\mathrm{H}_{2}$ further inhibited HeLa cell proliferation and promoted cell apoptosis. These data reveal that $\mathrm{H}_{2}$ has a dose-dependent role on cervical cancer HeLa cell suppression. Importantly, the increase in HeLa cell apoptotic rate induced by $5 \mu \mathrm{g} / \mathrm{ml}$ cisplatin treatment $\left(\mathrm{IC}_{50}=12 \mu \mathrm{g} / \mathrm{ml}\right)$ is similar to the effect of $66.7 \% \mathrm{H}_{2}$ treatment, suggesting that $\mathrm{H}_{2}$ therapy may 
A

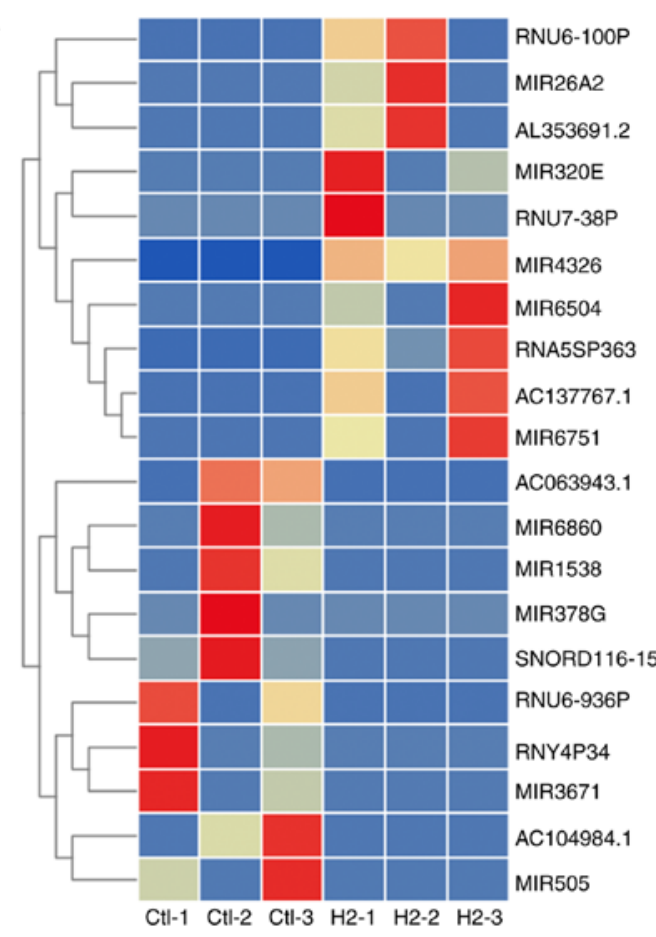

B

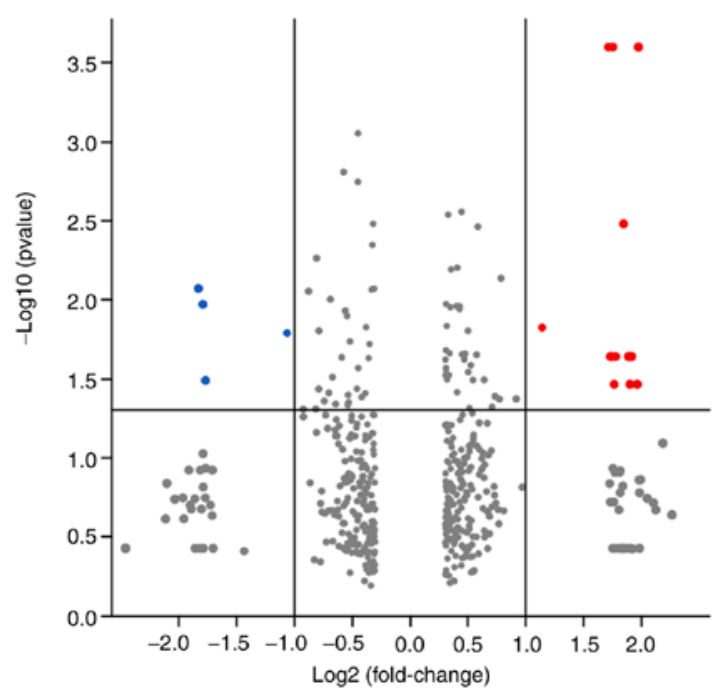

z-score

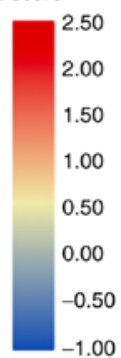

$-1.00$

Figure 4. Highly deregulated mRNAs in HeLa cells with or without $\mathrm{H}_{2}$ intervention. (A) A mRNA heatmap was generated based on the 10 maximum and 10 minimum FC values ( $\mathrm{n}=3$ per group). (B) Volcano plot for deregulated $\mathrm{mRNAs}[\log 2(\mathrm{FC})>1$ or $<-1$, adjusted $\mathrm{P}<0.05]$ between $\mathrm{H}_{2}$ and control groups. The area above the gray horizontal solid line indicates $\mathrm{P}<0.05$. (C) Upregulated mRNAs (red) and downregulated mRNAs (aqua blue) are listed. $\mathrm{H}_{2}$, hydrogen; FC, fold-change.

be a novel therapy for cervical cancer with less toxicity and efficacy comparable to chemotherapy.

Unexpectedly, $\mathrm{H}_{2}$ intervention reduced the oxidative stress levels, including decreased ROS and MDA concentrations, and increased SOD levels, which appeared to have the opposite effect on tumor cell suppression. The tumor inhibitory effect of $\mathrm{H}_{2}$ was then verified in HeLa tumor-bearing mice. The tumor volume at days 31 and 34 post-injection in tumor-bearing mice with continuous $\mathrm{H}_{2}$ treatment was significantly reduced compared with that of controls, and decreased tumor weight and cell proliferation as well as increased tumor cell apoptosis were also observed at day 34 post-injection. To explore the specific mechanisms of $\mathrm{H}_{2}$ on HeLa cell suppression, high-throughput RNA sequencing, including cirRNA, lncRNA, miRNA and mRNA sequencing, was performed. In cervical cancer, as well as in multiple other cancer types, short, non-coding single strands of RNAs, including circRNA, lncRNA and miRNA, play a vital role, since their deregulation has been widely reported (33-35). For example, miRNA may modulate oncogenic viral gene expression, as well as the 

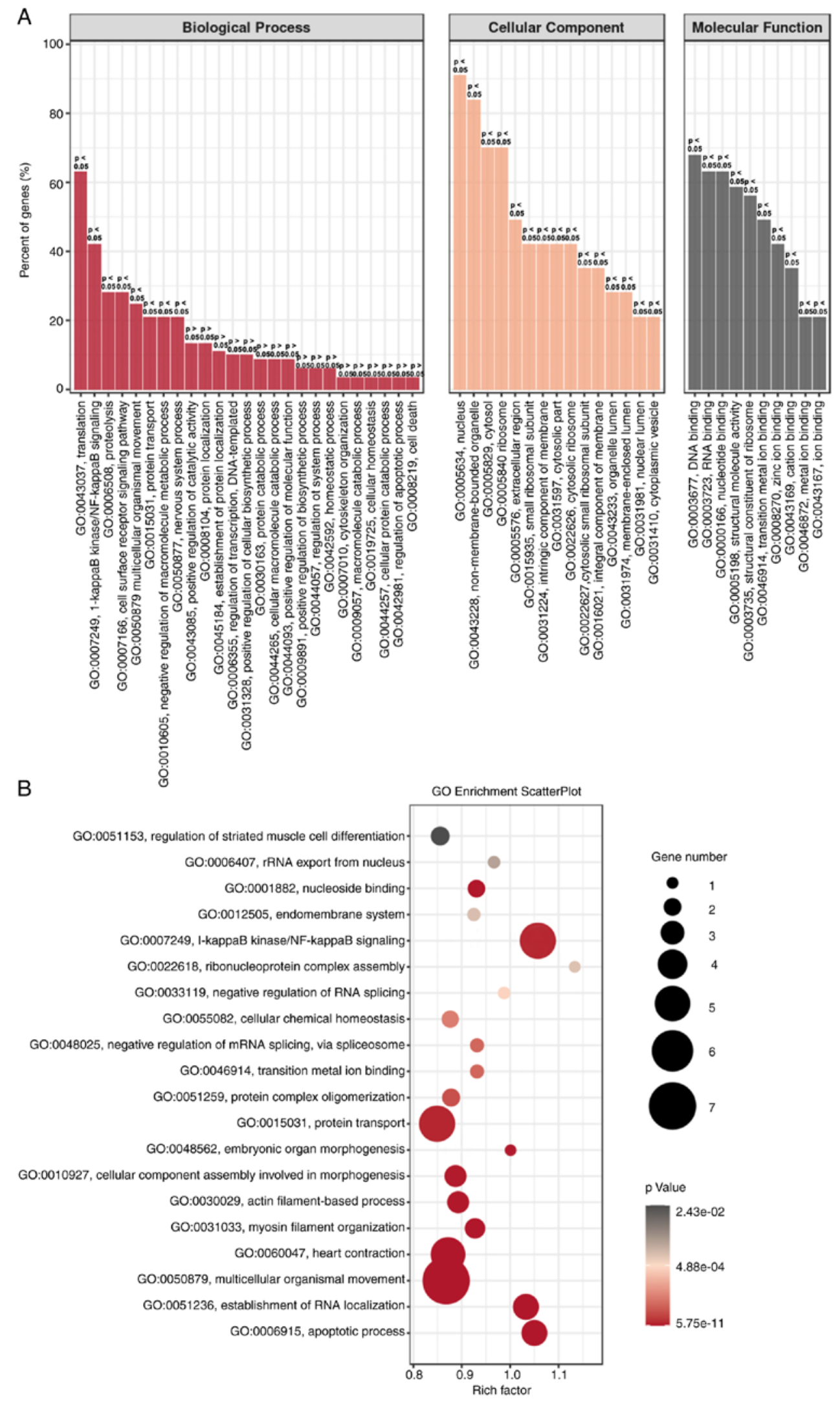

Figure 5. GO enrichment analysis of $\mathrm{H}_{2}$-treated HeLa cells. (A) $\mathrm{GO}$ enrichment of BP, $\mathrm{CC}$ and $\mathrm{MF}$ analysis between $\mathrm{H}_{2}$-treated HeLa cells and controls. (B) GO enrichment scatterplot for BP, CC and MF progress between HeLa cells with or without $\mathrm{H}_{2}$ treatment. GO, Gene Ontology; BP, biological process, CC, cellular component; $\mathrm{MF}$, molecular function; $\mathrm{H}_{2}$, hydrogen.

gene expression of the host (36). Specifically, miRNA genes may be located at the susceptible sites in the amplified or deleted genome/regions in human tumors (37). Furthermore, as miRNAs are associated with the regulation of cell proliferation and apoptosis, changes in their expression may be responsible for proliferative disease, including cancer (38). 

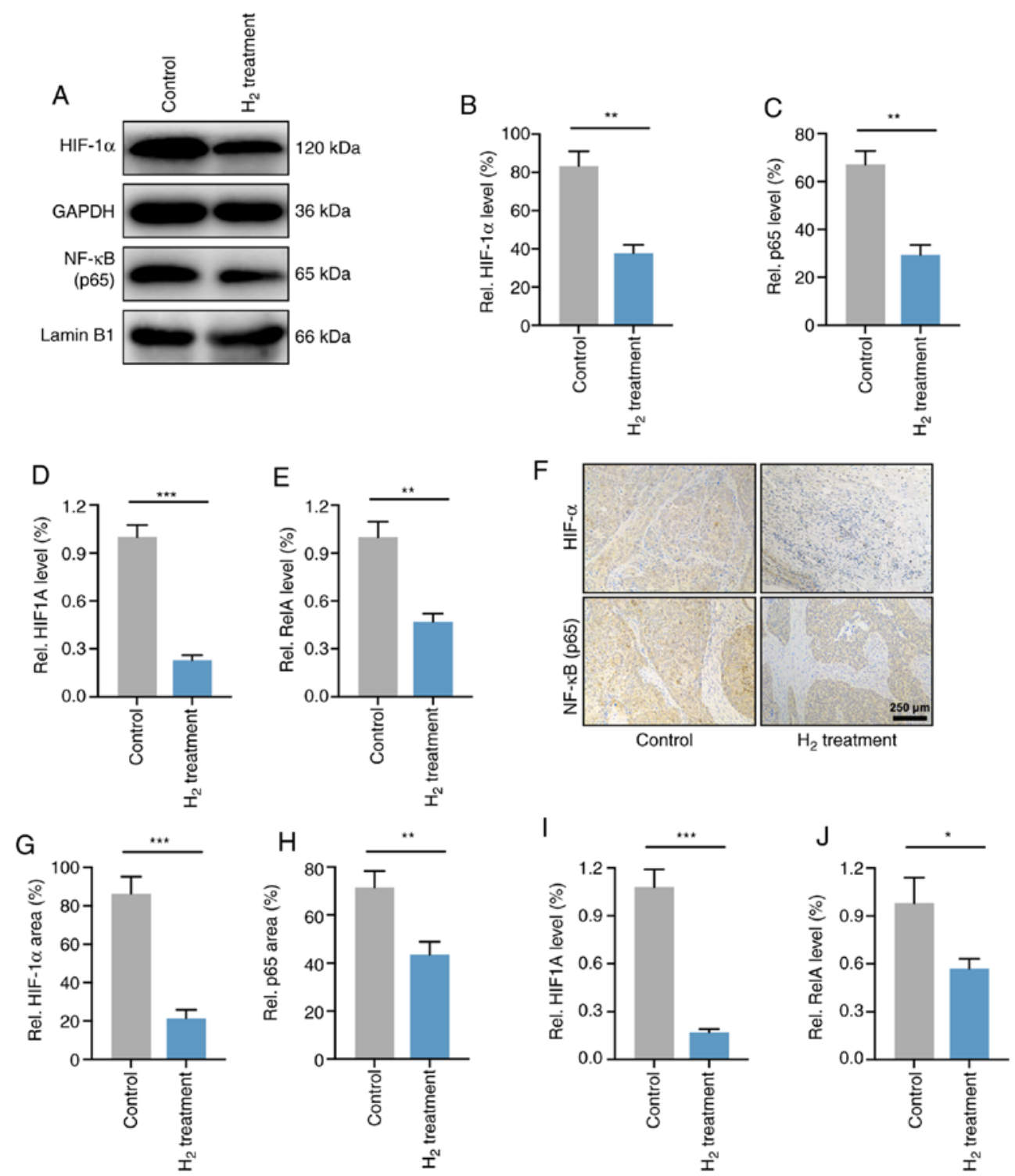

Figure 6. $\mathrm{H}_{2}$ treatment downregulates both the gene and post-transcriptional levels of HIF-1 $\alpha$ and NF- $\mathrm{kB}$ in HeLa cells and HeLa tumors. (A) Western blotting of HIF-1 $\alpha$ and NF-кB in control and $\mathrm{H}_{2}$-treated HeLa cells. Cytoplasmic (GAPDH) and nuclear (lamin B1) loading controls were used. (B and C) Statistical results of (B) HIF- $1 \alpha$ and (C) NF- $\kappa B$ protein expression levels in HeLa cells treated with $\mathrm{H}_{2}$ or not ( $\mathrm{n}=4$ per group). ${ }^{* *} \mathrm{P}<0.01$. RT-qPCR analysis for (D) HIF-1 $\alpha$ mRNA (HIF1A) and (E) NF- $\mathrm{kB}$ mRNA (RelA) levels in control and $\mathrm{H}_{2}$-treated HeLa cells ( $\mathrm{n}=4$ per group). ${ }^{* *} \mathrm{P}<0.01,{ }^{* * * *} \mathrm{P}<0.001$. (F) Immunohistochemical analysis for determining the HIF- $1 \alpha$ and NF- $\mathrm{KB}$ expression in tumor-bearing mice after $\mathrm{H}_{2}$ intervention and their controls (scale bar, $250 \mu \mathrm{m}$ ). Percentage of positive area of (G) HIF-1 $\alpha$ and (H) NF- $\mathrm{kB}$ in an in vivo xenograft model with or without $\mathrm{H}_{2}$ intervention ( $\mathrm{n}=9$ per group). ${ }^{* * *} \mathrm{P}<0.01,{ }^{* * * *} \mathrm{P}<0.001$. (I and J) RT-qPCR analysis for (I) HIFlA and (J) RelA expression in vivo ( $\mathrm{n}=9$ per group). ${ }^{*} \mathrm{P}<0.05,{ }^{* * * *} \mathrm{P}<0.001 . \mathrm{H}_{2}$, hydrogen; HIF, hypoxia inducible factor; RT-qPCR, reverse transcription-quantitative PCR.

The present study revealed that 11 circRNAs, 2 lncRNAs and 12 miRNAs were upregulated, and 16 circRNAs, 6 lncRNAs and 2 miRNAs were downregulated in $\mathrm{H}_{2}$-treated $\mathrm{HeLa}$ cells. These observations suggest that non-coding RNAs may account for the tumor inhibitory roles of $\mathrm{H}_{2}$ on HeLa cervical cancer cells, but the specific mechanism needs to be further explored.

In addition, RNA sequencing demonstrated the changes in expression of several genes closely associated with tumor development, such as HIFIA and RelA, which encode HIF-1 $\alpha$ and NF- $\kappa$ B p65 subunit, respectively. GO analysis further indicated that NF- $\mathrm{\kappa B}$ signaling was involved in the inhibitory mechanism of $\mathrm{H}_{2}$-treated HeLa cells. Declined expression of HIFlA and RelA and their translated HIF-1 $\alpha$ and NF- $\mathrm{kB}$ p65 proteins was then confirmed by RT-qPCR, western blotting and IHC both in vitro and in vivo. p65 subunit is a classic active type of the NF- $\kappa B$ family (28). It has been reported that $\mathrm{NF}-\kappa \mathrm{B}$ p65 is a molecular lynchpin that links chronic infection and inflammation with elevated cancer risk (39). NF- $\kappa B$ is persistently activated in multiple types of cancer and exerts a variety of pro-tumorigenic functions. For example, NF- $\kappa \mathrm{B}$ activation in cancer cells usually leads to the elevation of anti-apoptotic genes to provide a cell survival mechanism for resisting the physiological stress that induces inflammation (40). Furthermore, NF- $\kappa B$ stimulates cytokines that regulate the immune response and inflammation, including TNF- $\alpha$, IL-1, IL-6 and IL-8, as well as adhesion molecules, which result in the recruitment of leukocytes to inflammatory sites $(28,40)$. In addition, $N F-\kappa B$ signaling was shown to modulate various other conserved cellular processes, including 
cell proliferation $(41,42)$ and apoptosis $(43) . \mathrm{H}_{2}$ intervention in HeLa cells and tumors was demonstrated to reduce both NF- $\kappa$ B p65 protein and mRNA levels in the RNA-sequencing and molecular biology experiments of the present study, suggesting a decrease in inflammatory response and tumor growth.

In cancer, hypoxia is considered as a vital characteristic of the tumor microenvironment that drives tumor progression $(44,45)$. Hypoxic adaptation is largely modulated by a group of transcriptional regulators named hypoxia-inducible factors (HIFs) (46). HIF is a heterotrimeric complex consisting of an $\mathrm{O}_{2}$-regulated $\alpha$-subunit and an $\mathrm{O}_{2}$-independent $\beta$-subunit (also called aryl hydrocarbon receptor nuclear translocator) (47). There are three HIF- $\alpha$ proteins recognized in humans: HIF- $1 \alpha,-2 \alpha$ and $-3 \alpha$. Under normal $\mathrm{O}_{2}$ conditions, HIF- $\alpha$ subunits are tightly modulated by a series of enzymes called HIF prolyl hydroxylases (PHDs). PHD is a non-heme Fe (II)- and 2-oxoglutarate-dependent dioxygenase that hydroxylates HIF- $\alpha$ subunits at specific prolyl residues. The hydroxylated HIF- $\alpha$ subunits are identified by the von-Hippel Lindau tumor-suppressor E3 ligase and degraded via the proteasome pathway $(46,47)$. Intratumoral hypoxia induces both HIF-1 and HIF-2 activation, and overexpression of HIF- $1 \alpha$ is strongly associated with elevated metastasis and mortality in numerous human cancer types $(45,48)$, including cervical cancer (49). Upregulated HIF-1 $\alpha$ in these cancer types results in a series of regulatory processes leading to tumor progression, including migration, invasion, angiogenesis, glucose metabolism and $\mathrm{pH}$ regulation $(44,45,50,51)$.

The present study demonstrated that both HIF1A (HIF-1 $\alpha$ gene) and HIF-1 $\alpha$ protein levels were reduced in $\mathrm{H}_{2}$-treated HeLa cells and HeLa tumors, which is important for elucidating the potential mechanisms of $\mathrm{H}_{2}$ gas on cervical cancer treatment. Notably, the reduced oxidative stress observed in HeLa cells may contradict the antitumor effects of $\mathrm{H}_{2}$. However, since ROS are essential in the stabilization of HIF that maintains the transcription of genes involved in tumor development (52), this downward trend of oxidative stress may be considered as an antitumor effect in general. Additionally, since HeLa cells are infected by HPV18 and its mechanism is associated with the regulation of oxidative stress (53), it could be hypothesized that $\mathrm{H}_{2}$ intervention may also regulate the HPV18 genome in HeLa cells, thereby exerting a tumor-suppressor effect. Future research on this topic needs to be conducted.

The present study also has several limitations. As one of numerous cervical cancer cell lines, experiments solely on HeLa cell cells cannot determine whether all types of cervical cancer cells exhibit a consistent effect after $\mathrm{H}_{2}$ intervention, and therefore additional cell types need to be further evaluated. Furthermore, the grow th characteristics of cervical cancer cells is affected in a subcutaneous tumor model in the present study, therefore the effects of $\mathrm{H}_{2}$ treatment are different from what would be seen in human cervical cancer. The establishment of an in situ cervical cancer model in follow-up experiments is therefore needed. In addition, the specific mechanism of the inhibitory effect of $\mathrm{H}_{2}$ on $\mathrm{HIF}-1 \alpha$ and NF- $\kappa \mathrm{B}$ (such as the regulation of the transcriptional levels of HIFIA and RelA) needs to be verified in further research. Also, the lack of negative and positive controls in this study may lead to a deviation in IHC results to a certain extent.
In conclusion, the present study suggests a novel $\mathrm{H}_{2}$-induced tumor suppression target towards $\mathrm{HIF}-1 \alpha$ and $\mathrm{NF}-\kappa \mathrm{B}$. Inhibition of HIF- $1 \alpha$ and $\mathrm{NF}-\kappa \mathrm{B}$ reduces cervical cancer HeLa cell proliferation and oxidative stress level, and decreases tumor growth, which makes $\mathrm{H}_{2}$ therapy a potential target in the treatment of cervical cancer.

\section{Acknowledgements}

Not applicable.

\section{Funding}

This work was supported by a grant from the National Military Health Care Project (2016CGGS03).

\section{Availability of data and materials}

The datasets generated and/or analyzed during the current study are available in the Sequence Read Archive repository (https://www.ncbi.nlm.nih.gov/sra/?term=PRJNA718006), with accession number: PRJNA718006.

\section{Authors' contributions}

$\mathrm{JC}, \mathrm{XL}$, and ZJ conceived and designed the research. JC, JG, $\mathrm{JW}, \mathrm{LL}$ and GC performed the in vitro and in vivo experiments. JD and ZW performed the RNA sequencing and analyzed the data. JC, JG, and XL were responsible for data analysis and writing of the manuscript. All the authors listed have approved the final manuscript.

\section{Ethics approval and consent to participate}

All animal experiments were performed in accordance with the National Institutes of Health (NIH) Guide for the Care and Use of Laboratory Animals, and were approved by the Ethics Committee for Animal Studies of Naval Medical University (approval number: 202027).

\section{Patient consent for publication}

Not applicable.

\section{Competing interests}

The authors declare that they have no competing interests.

\section{References}

1. Bray F, Ferlay J, Soerjomataram I, Siegel RL, Torre LA and Jemal A: Global cancer statistics 2018: GLOBOCAN estimates of incidence and mortality worldwide for 36 cancers in 185 countries. CA Cancer J Clin 68: 394-424, 2018.

2. Siegel RL, Miller KD and Jemal A: Cancer statistics, 2020. CA Cancer J Clin 70: 7-30, 2020.

3. Landoni F, Maneo A, Colombo A, Placa F, Milani R, Perego P, Favini G, Ferri L and Mangioni C: Randomised study of radical surgery versus radiotherapy for stage Ib-IIa cervical cancer. Lancet 350: 535-540, 1997.

4. Neeman E and Ben-Eliyahu S: Surgery and stress promote cancer metastasis: New outlooks on perioperative mediating mechanisms and immune involvement. Brain Behav Immun 30 (Suppl 1): S32-S40, 2013 
5. Hodson R: Precision medicine. Nature 537: S49, 2016.

6. Tannock IF and Hickman JA: Limits to personalized cancer medicine. N Engl J Med 375: 1289-1294, 2016.

7. Sano M, Suzuki M, Homma K, Hayashida K, Tamura T, Matsuoka T, Katsumata Y, Onuki S and Sasaki J: Promising novel therapy with hydrogen gas for emergency and critical care medicine. Acute Med Surg 5: 113-118, 2017.

8. Ge L, Yang M, Yang NN, Yin XX and Song WG: Molecular hydrogen: A preventive and therapeutic medical gas for various diseases. Oncotarget 8: 102653-102673, 2017.

9. Ohta S: Molecular hydrogen as a preventive and therapeutic medical gas: Initiation, development and potential of hydrogen medicine. Pharmacol Ther 144: 1-11, 2014.

10. Tamura T, Suzuki M, Hayashida K, Kobayashi Y, Yoshizawa J, Shibusawa T, Sano M, Hori S and Sasaki J: Hydrogen gas inhalation alleviates oxidative stress in patients with post-cardiac arrest syndrome. J Clin Biochem Nutr 67: 214-221, 2020.

11. Chen L, Chao Y, Cheng P, Li N, Zheng H and Yang Y: UPLC-QTOF/MS-based metabolomics reveals the protective mechanism of hydrogen on mice with ischemic stroke. Neurochem Res 44: 1950-1963, 2019.

12. Yang Y, Liu PY, Bao W, Chen SJ, Wu FS and Zhu PY: Hydrogen inhibits endometrial cancer growth via a ROS/NLRP3/caspase-1/GSDMD-mediated pyroptotic pathway. BMC Cancer 20: 28, 2020

13. Wang D, Wang L, Zhang Y, Zhao Y and Chen G: Hydrogen gas inhibits lung cancer progression through targeting SMC3. Biomed Pharmacother 104: 788-797, 2018.

14. Harguindey S, Alfarouk K, Orozco JP, Hardonniere K, Stanciu D, Fais S and Devesa J: A new and integral approach to the etiopathogenesis and treatment of breast cancer based upon its hydrogen ion dynamics. Int J Mol Sci 21: 1110, 2020.

15. Chen JB, Kong XF, Lv YY, Qin SC, Sun XJ, Mu F, Lu TY and $\mathrm{Xu}$ KC: 'Real world survey' of hydrogen-controlled cancer: A follow-up report of 82 advanced cancer patients. Med Gas Res 9: $115-121,2019$.

16. Andrews KR, Good JM, Miller MR, Luikart G and Hohenlohe PA Harnessing the power of RADseq for ecological and evolutionary genomics. Nat Rev Genet 17: 81-92, 2016.

17. Masters JR: HeLa cells 50 years on: The good, the bad and the ugly. Nat Rev Cancer 2: 315-319, 2002.

18. Nagaraj N, Wisniewski JR, Geiger T, Cox J, Kircher M, Kelso J, Pääbo $\mathrm{S}$ and Mann M: Deep proteome and transcriptome mapping of a human cancer cell line. Mol Syst Biol 7: 548, 2011

19. Tavakolian S, Goudarzi H, Eslami $G$ and Faghihloo E: Transcriptional regulation of epithelial to mesenchymal transition related genes by lipopolysaccharide in human cervical cancer cell line HeLa. Asian Pac J Cancer Prev 20: 2455-2461, 2019.

20. Johrens K, Lazzerini L, Barinoff J, Sehouli J and Cichon G Mesothelin as a target for cervical cancer therapy. Arch Gynecol Obstet 299: 211-216, 2019.

21. Lin Y, Ohkawara B, Ito M, Misawa N, Miyamoto K, Takegami Y, Masuda A, Toyokuni S and Ohno K: Molecular hydrogen suppresses activated Wnt//-catenin signaling. Sci Rep 6: 31986, 2016.

22. Kamalipooya S, Abdolmaleki P, Salemi Z, Javani Jouni F, Zafari J and Soleimani H: Simultaneous application of cisplatin and static magnetic field enhances oxidative stress in HeLa cell line. In Vitro Cell Dev Biol Anim 53: 783-790, 2017.

23. Metsalu T and Vilo J: ClustVis: A web tool for visualizing clustering of multivariate data using principal component analysis and heatmap. Nucleic Acids Res 43: W566-W570, 2015.

24. Huang da W, Sherman BT and Lempicki RA: Systematic and integrative analysis of large gene lists using DAVID bioinformatics resources. Nat Protoc 4: 44-57, 2009.

25. Rao X, Huang X, Zhou Z and Lin X: An improvement of the $2^{\wedge}$ (-delta delta CT) method for quantitative real-time polymerase chain reaction data analysis. Biostat Bioinforma Biomath 3: 71-85, 2013.

26. Finkel T and Holbrook NJ: Oxidants, oxidative stress and the biology of ageing. Nature 408: 239-247, 2000.

27. Costa V and Moradas-Ferreira P: Oxidative stress and signal transduction in Saccharomyces cerevisiae: Insights into ageing, apoptosis and diseases. Mol Aspects Med 22: 217-246, 2001.

28. DiDonato JA, Mercurio F and Karin M: NF- $\kappa$ B and the link between inflammation and cancer. Immunol Rev 246: 379-400, 2012.

29. Trottier $\mathrm{H}$ and Burchell AN: Epidemiology of mucosal human papillomavirus infection and associated diseases. Public Health Genomics 12: 291-307, 2009
30. McBride AA: Oncogenic human papillomaviruses. Philos Trans R Soc Lond B Biol Sci 372: 20160273, 2017.

31. Viarisio D, Gissmann L and Tommasino M: Human papillomaviruses and carcinogenesis: Well-established and novel models. Curr Opin Virol 26: 56-62, 2017.

32. St Laurent J, Luckett R and Feldman S: HPV vaccination and the effects on rates of HPV-related cancers. Curr Probl Cancer 42 493-506, 2018

33. Tornesello ML, Faraonio R, Buonaguro L, Annunziata C, Starita N, Cerasuolo A, Pezzuto F, Tornesello AL and Buonaguro FM: The role of microRNAs, long non-coding RNAs, and circular RNAs in cervical cancer. Front Oncol 10: 150, 2020.

34. Casarotto M, Fanetti G, Guerrieri R, Palazzari E, Lupato V, Steffan A, Polesel J, Boscolo-Rizzo P and Fratta E: Beyond microRNAs: Emerging role of other non-coding RNAs in HPV-driven cancers. Cancers (Basel) 12: 1246, 2020.

35. Wen X, Liu S, Sheng J and Cui M: Recent advances in the contribution of noncoding RNAs to cisplatin resistance in cervical cancer. PeerJ 8: e9234, 2020

36. Vojtechova $Z$ and Tachezy R: The role of miRNAs in virus-mediated oncogenesis. Int J Mol Sci 19: 1217, 2018.

37. Calin GA and Croce CM: MicroRNA-cancer connection: The beginning of a new tale. Cancer Res 66: 7390-7394, 2006.

38. Gaur A, Jewell DA, Liang Y, Ridzon D, Moore JH, Chen C, Ambros VR and Israel MA: Characterization of microRNA expression levels and their biological correlates in human cancer cell lines. Cancer Res 67: 2456-2468, 2007.

39. Taniguchi $\mathrm{K}$ and Karin M: NF- $\kappa \mathrm{B}$, inflammation, immunity and cancer: Coming of age. Nat Rev Immunol 18: 309-324, 2018.

40. Hoesel B and Schmid JA: The complexity of NF- $\kappa$ B signaling in inflammation and cancer. Mol Cancer 12: 86, 2013.

41. Guttridge DC, Albanese C, Reuther JY, Pestell RG and Baldwin AS Jr: NF-kappaB controls cell growth and differentiation through transcriptional regulation of cyclin D1. Mol Cell Biol 19: 5785-5799, 1999.

42. La Rosa FA, Pierce JW and Sonenshein GE: Differential regulation of the c-myc oncogene promoter by the NF-kappa B rel family of transcription factors. Mol Cell Biol 14: 1039-1044, 1994

43. Perkins ND: Achieving transcriptional specificity with NF-kappa B. Int J Biochem Cell Biol 29: 1433-1448, 1997.

44. Vaupel P and Mayer A: Hypoxia in tumors: Pathogenesis-related classification, characterization of hypoxia subtypes, and associated biological and clinical implications. Adv Exp Med Biol 812: 19-24, 2014

45. Zhou J, Schmid T, Schnitzer S and Brune B: Tumor hypoxia and cancer progression. Cancer Lett 237: 10-21, 2006.

46. Semenza GL: Oxygen sensing, hypoxia-inducible factors, and disease pathophysiology. Annu Rev Pathol 9: 47-71, 2014.

47. Wenger RH, Stiehl DP and Camenisch G: Integration of oxygen signaling at the consensus HRE. Sci STKE 2005: re12, 2015.

48. Zhong H, De Marzo AM, Laughner E, Lim M, Hilton DA, Zagzag D, Buechler P, Isaacs WB, Semenza GL and Simons JW: Overexpression of hypoxia-inducible factor lalpha in common human cancers and their metastases. Cancer Res 59: 5830-5835, 1999.

49. Seeber LM, Horree N, Vooijs MA, Heintz AP, van der Wall E, Verheijen RH and van Diest PJ: The role of hypoxia inducible factor-1alpha in gynecological cancer. Crit Rev Oncol Hematol 78: 173-184, 2011

50. Keith B, Johnson RS and Simon MC: HIF1 $\alpha$ and HIF2 $\alpha$ : Sibling rivalry in hypoxic tumour growth and progression. Nat Rev Cancer 12: 9-22, 2011.

51. Scholz CC and Taylor CT: Targeting the HIF pathway in inflammation and immunity. Curr Opin Pharmacol 13: 646-653, 2013.

52. Hervouet E, Cizkova A, Demont J, Vojtiskova A, Pecina P, Franssen-van Hal NL, Keijer J, Simonnet H, Ivanek R, Kmoch S, et al: HIF and reactive oxygen species regulate oxidative phosphorylation in cancer. Carcinogenesis 29: 1528-1537, 2008.

53. Hao Y, Yan Z, Zhang A, Hu S, Wang N, Luo XG, Ma W, Zhang TC and He H: IL-6/STAT3 mediates the HPV18 E6/E7 stimulated upregulation of MALAT1 gene in cervical cancer HeLa cells. Virus Res 281: 197907, 2020

This work is licensed under a Creative Commons

Attribution-NonCommercial-NoDerivatives 4.0 International (CC BY-NC-ND 4.0) License. 